\title{
Growth of abalone (Haliotis discus hannai) in cages using epibiont control measures
}

\author{
Jido Han, Mi Ae Jeon, Da Woon Kim, Hon Park, Byong Hak Kim, Deok Chan Lee* \\ South Sea Fisheries Research Institute, National Institute of Fisheries Science, Yeosu 58780, Korea
}

\begin{abstract}
In this study, the relationship between the growth of abalone and the presence of epibionts was investigated in abalone cultured in Goheung, Jeollanam-do, where there are severe problems high water temperatures and attachment. The experiment was conducted for eight months (May-December 2020), and 40 abalone were collected every month. Water temperature was at its highest at a range of $13.5^{\circ} \mathrm{C}-26.6^{\circ} \mathrm{C}$ and dissolved oxygen levels were at their lowest at a range of $4.0-10.2 \mu \mathrm{g} / \mathrm{L}$ in August. The shell height $(\mathrm{mm})$ of abalone grew to $117.7 \%(81.8 \pm 1.9 \mathrm{~mm})$ in cultures where epibionts were removed $(\mathrm{ER})$ and $111 \%(77.4 \pm$ $3.3 \mathrm{~mm}$ ) where they were not (non-epibionts, NER). Their total weight (TW) and body weight increased significantly and steadily with ER, whereas the TW increased sharply after August with NER. In the condition index, no significant difference was observed between ER and NER. The monthly proportion of epibionts increased significantly in July, accounting for the value of $69.9 \%$ reached in December.
\end{abstract}

Keywords: Growth, Cage culture, Abalone, Haliotis discus hannai, Epibiont

\section{Introduction}

Since 2000, the abalone farming industry in Korea has soared due to an increase in fishing licenses issued and cage facilities; in 2019, 20059 tons of abalone were produced at a value of approximately KRW 610.3 billion (KNSO, 2019). Most abalone farms are in Jeollanam-do and account for $98 \%$ of the total production in Korea (Shin et al., 2017).

Abalone farming uses cages and is greatly affected by natural changes (e.g., climatic and other disasters). Due to recent climate change factors, the number of epibionts in cage facilities and on abalone shells is increasing as the water temperature in abalone farming areas increases, and it has been reported that this causes problems such as impaired growth, increased mortality, and a decrease in product value (Won et al., 2013). Epibionts growing on abalone shells make feeding and other farming activities difficult. Another threat is that breeding holes are blocked by the epibionts. The cost of removing the epibionts is KRW 20 billion per year. However, there is a lack of studies on the effects of and possible control measures for epibionts.

In this study, the growth of abalone according to the proportion of epibionts present was investigated for abalone

Received: Aug 3, 2021 Revised: Sep 24, 2021 Accepted: Dec 8, 2021

*Corresponding author: Deok Chan Lee

South Sea Fisheries Research Institute, National Institute of Fisheries Science, Yeosu 58780, Korea

Tel: +82-61-659-8980, Fax: +82-61-685-9073, E-mail: saranghase@korea.kr

This is an Open Access article distributed under the terms of the Creative Commons Attribution Non-Commercial License (http://creativecommons.org/licenses/by$\mathrm{nc} / 4.0 /$ ) which permits unrestricted non-commercial use, distribution, and reproduction in any medium, provided the original work is properly cited.

Copyright $\odot 2021$ The Korean Society of Fisheries and Aquatic Science 
cultured in Goheung, Jeollanam-do, where high water temperatures and attachment problems have been steadily increasing.

\section{Materials and Methods}

\section{Abalone specimens}

In this study, Haliotis discus hannai raised it in a cage in Goheung (Geumsan-myeon, Goheung-gun), Jeollanam-do at a standard density of less than $4 \mathrm{~cm}$ ( $4 \mathrm{~cm}, 2,000$ abalone), and then divided it into two cages and raised it for eight months (May-December 2020). In one cage (epibiont removal, ER), the epibionts were removed once, in August, and in the other cage (non-epibiont removal, NER) the abalone were raised for eight months without removing the epibionts. Forty abalone were collected every month and the shells of these individuals were measured for shell height (SH, mm), shell length (SL, mm), total weight (TW, g), and body weight (BW, g); they were then and analyzed for the condition index (CI).

$$
\mathrm{CI}=\text { Body weight }(\mathrm{g}) / \text { Shell length }{ }^{3}
$$

\section{Epibiont species and proportions}

Each month, the species of epibiont on the abalone shells were classified based on their morphological characteristics and the proportion (\%) of the three dominant species among them was analyzed. In addition, the weight of the attachment was dropped using an air chipper (ECO20-L, Ecotool, Smith, Seoul, Korea), and the weight was measured:

$$
\begin{aligned}
\text { Proportion }(\%)= & \text { Area of epibiont }\left(\mu \mathrm{m}^{2}\right) \times 100 / \text { Area of } \\
& \text { abalone shell }\left(\mu \mathrm{m}^{2}\right)
\end{aligned}
$$

\section{Environmental conditions}

A real-time water temperature probe (Hobo water temperature Pro V2, Onset, Bourne, MA, USA) was installed in the cage (at a depth of $2.5 \mathrm{~m}$ ) to measure the water temperature $\left({ }^{\circ} \mathrm{C}\right)$ and dissolved oxygen $(\mathrm{mg} / \mathrm{L})$ at intervals of $15 \mathrm{~min}$.

\section{Statistical analysis}

One-way analysis of variance (ANOVA) was performed using SPSS (version 20.0; SPSS, Chicago, IL, USA). The test was used to examine the statistical significance of the mean values at a $95 \%$ confidence interval.

\section{Results}

Daily variations in water temperature and dissolved oxygen from May to December 2020 are shown in Fig. 1. In August, the water temperature was highest at a range from $13.5^{\circ} \mathrm{C}$ to $26.6^{\circ} \mathrm{C}$ and dissolved oxygen was lowest at a range from 4.0 to $10.2 \mathrm{mg} / \mathrm{L}$; however, these were within the ranges for normal abalone habitat.

The SH $(\mathrm{mm})$ of the abalone grew by $117.7 \%(81.8 \pm 1.9$ $\mathrm{mm})$ in the ER and $111 \%(77.4 \pm 3.3 \mathrm{~mm})$ in the NER compared to the initial measurements (69.61 mm) (Fig. 2). During the study period, the TW and BW increased significantly and steadily in the ER condition, whereas after August the TW increased sharply in the NER, while the BW tended to decrease (Fig. 3). No significant difference was observed in the CI between the ER and NER (Fig. 4).

Among the epibionts on the surface of abalone shells, the most dominant species were Pacific oysters (Crassostrea gigas), barnacles (Chthalamus spp.), and hydroid warms (Table 1). Analysis of the monthly proportion of epibionts showed that this increased significantly from July until it reached a value of $69.9 \%$ in December. Oysters accounted for the highest percentage of attachments (40.6\%), followed by barnacles (27.3\%); the ratio of oysters and barnacles was similar until August but increased sharply from September (Fig. 5).

\section{Discussion}

In Korea, abalone is mainly grown in cages; therefore, their survival and growth are greatly influenced by exogenous factors (Kim et al., 2005; Lee, 2014; Park et al., 2013; Shin et al., 2011). Abalone growth is closely related to water temperature (Britz et al., 1997; Cho \& Cho, 2009; Sakai, 1962), density (Capinpin et al., 1999; Kim et al., 2013a; Kim et al., 2014; Yoon et al., 2014), and diets (Kim et al., 2003; Kim et al., 2013b; Lee et al., 1999).

In this study, the abalone were raised at a standard density and the factors affecting their growth-including the equitable supply and management of Laminaria japonica for food-were minimized.

Recently, the value of abalone has been decreasing due to the presence of epibionts, and the cost of removing them is increasing every year. Abalone shell attachments can be both internal and external; perforation by Polydora, which are internal attachments, do not cause death; however, they have been reported to reduce abalone growth and weight and increase stress (Bower et al., 1994; Kent, 1979; Won et al., 2013). However, 


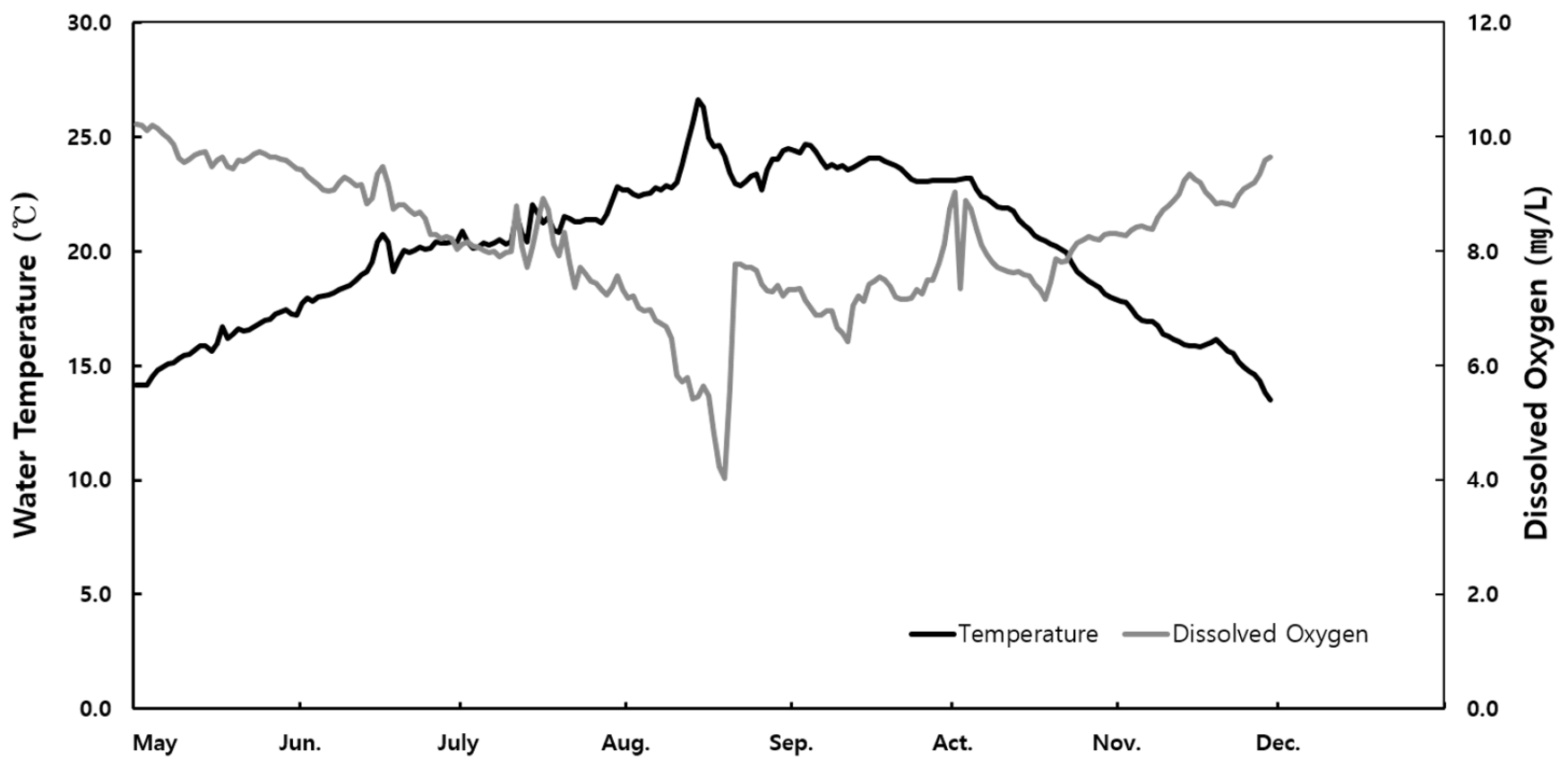

Fig. 1. Daily mean water temperature and dissolved oxygen in a cage in Goheung.

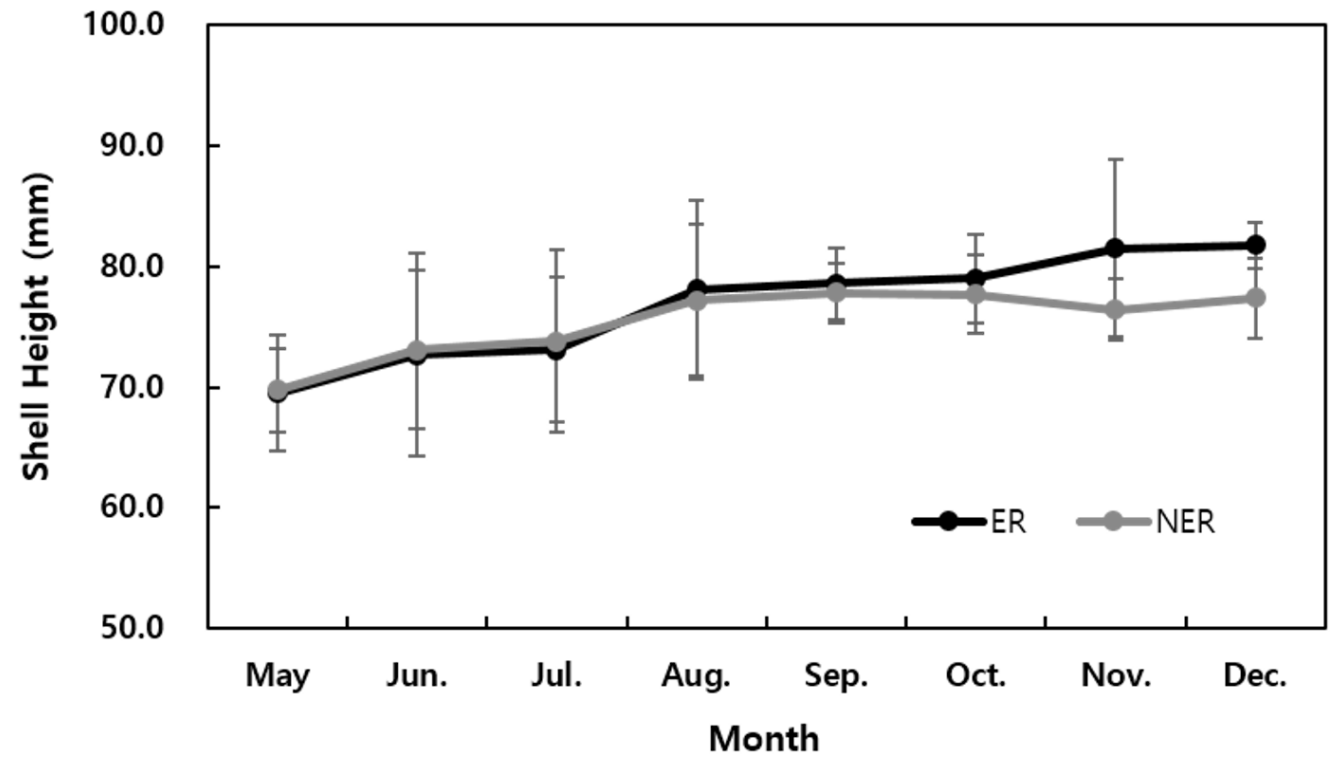

Fig. 2. Monthly variations in shell height ( $\mathrm{mm}$ ) of Haliotis discus hannai. ER, epibiont removal; NER, non-epibionts removal.

there is a lack of studies on the effects of and control measures for organisms that attach externally on abalone.

In addition, this study revealed that the proportion of epibionts increased after September; barnacles, in particular, increased after June. The spawning period of oysters and barnacles were late
August and early June, respectively (Kim et al., 2009).

The proportion of epibionts differed according to the growth of the attachments. SHs, TWs, and BWs increased significantly from September in the ER group; however, the SHs did not increase in the NER group and the BWs tended to 

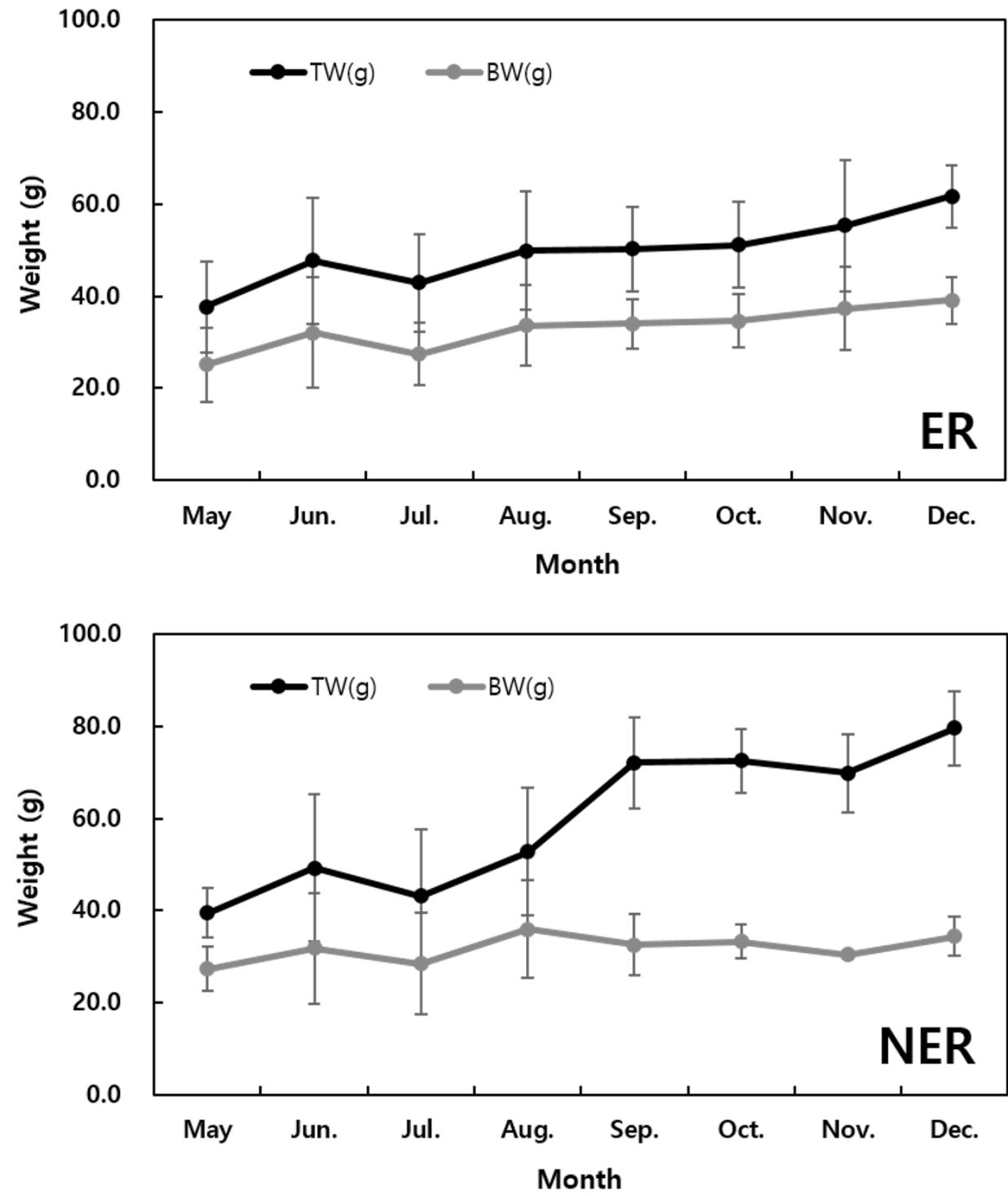

Fig. 3. Monthly variations of weight(g) in Haliotis discus hannai. TW, total weight; BW, body weight; ER, epibionts removal; NER, non-epibionts removal.

decrease. These findings suggest that epibionts affect abalone growth indirectly.

Although epibionts have adverse effects on ship hulls, fish cages, seaside facilities, and aquaculture in various forms, domestic research on this topic is insufficient (Park, 1980; Shim \& Jung, 1987). Therefore, it seems that more control studies using the spawning time and attraction substrate of the attachments, as well as a study on the effect of these on abalone, are necessary.

\section{Competing interests}

No potential conflict of interest relevant to this article was reported.

\section{Funding sources}

This work was supported by a grant from the National Institute of Fisheries Science (grant number R2021019).

\section{Acknowledgements}

Not applicable.

\section{Availability of data and materials}

Upon reasonable request, the datasets of this study can be available from the corresponding author. 


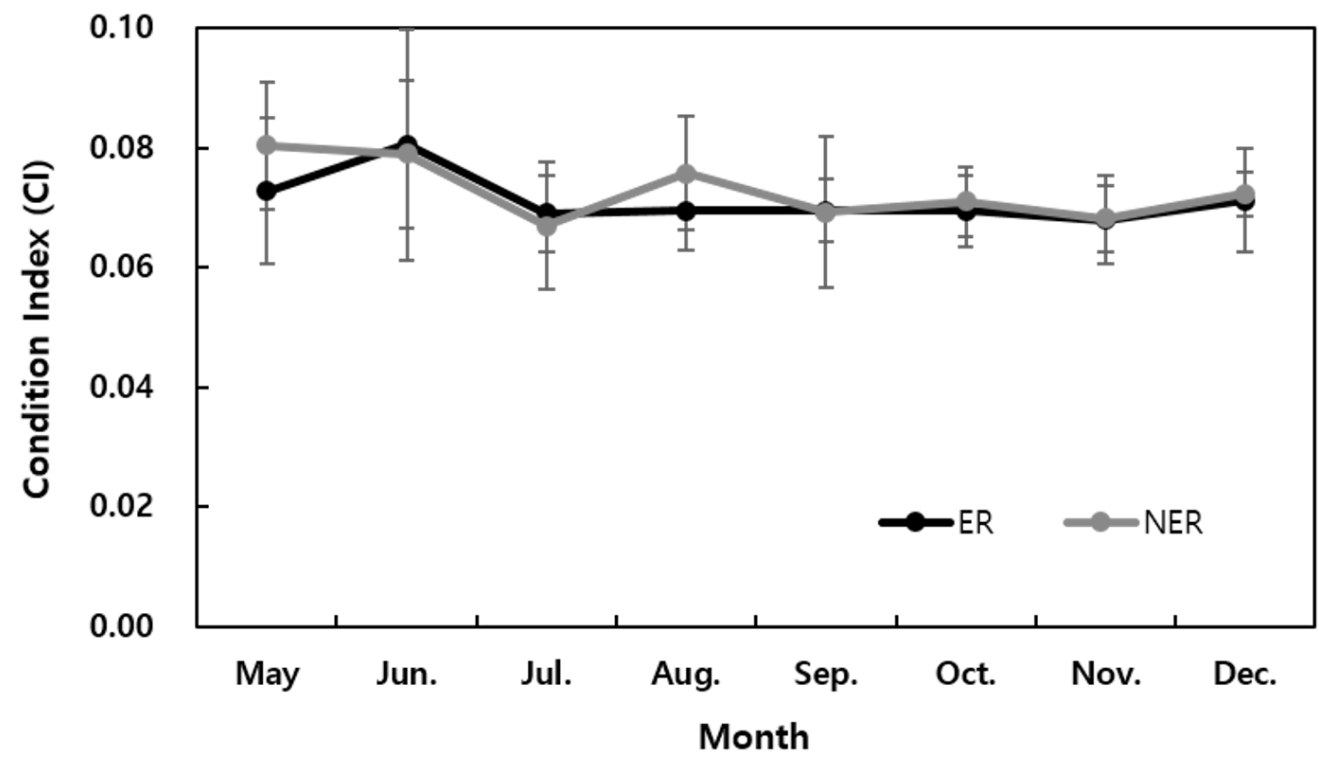

Fig. 4. Monthly variations in condition index (CI) for Haliotis discus hannai. ER, epibiont removal; NER, non-epibiont removal.

Table 1. Occurrence of epibionts on the surface of abalone shells in Goheung

\begin{tabular}{ll}
\hline Epibionts & Occurrence (\%) \\
\hline Total & 69.9 \\
Pacific oyster (Crassostrea gigas) & 40.6 \\
Barnacles (Chthalamus spp.) & 27.3 \\
Hydroid warms & 2.0 \\
\hline
\end{tabular}

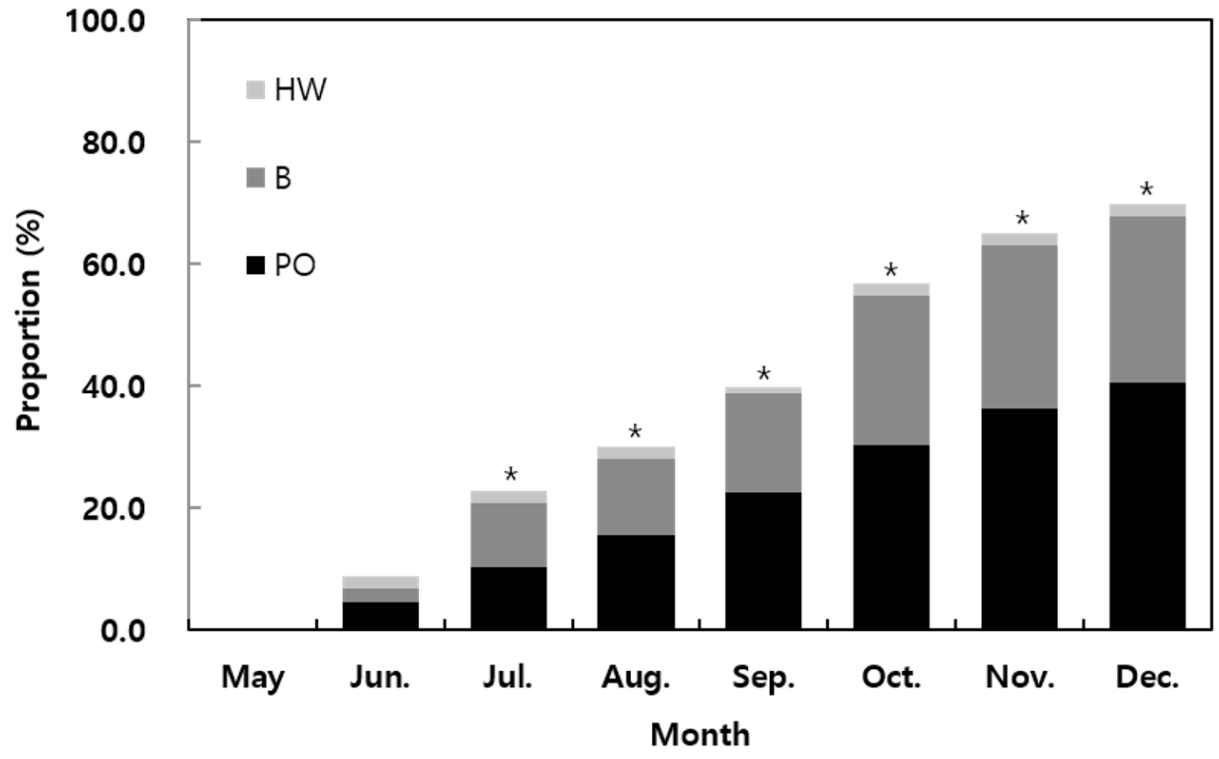

Fig. 5. Monthly variations in the proportion of epibiont on Haliotis discus hannai. $\mathrm{B}$, barnacles; HW, hydroid warms; $\mathrm{PO}$, pacific oyster. "Statistically significant difference from the initial proportion (May) (ANOVA, $p<0.05$ ). 


\section{Ethics approval and consent to participate}

This article does not require IRB/IACUC approval because there are no human and animal participants.

\section{ORCID}

Jido Han

Mi Ae Jeon

Da Woon Kim

Hon Park

Byong Hak Kim

Deok Chan Lee https://orcid.org/0000-0001-9905-5076

https://orcid.org/0000-0001-9230-1334

https://orcid.org/0000-0001-5357-9835

https://orcid.org/0000-0003-4314-9377

https://orcid.org/0000-0003-2448-8373

https://orcid.org/0000-0002-1211-0317

\section{References}

Bower SM, McGladdery SE, Price IM. Synopsis of infectious diseases and parasites of commercially exploited shellfish. Annu Rev Fish Dis. 1994;4:1-199.

Britz PJ, Hecht T, Mangold S. Effect of temperature on growth, feed consumption and nutritional indices of Haliotis midae fed a formulated diet. Aquaculture. 1997;152:191-203.

Capinpin EC Jr, Toledo JD, Encena VC 2nd, Doi M. Density dependent growth of the tropical abalone Haliotis asinina in cage culture. Aquaculture. 1999;171:227-35.

Cho SH, Cho YJ. Effect of temperature condition on growth of juvenile abalone, Haliotis discus hannai with the different feeds. Korean J Malacol. 2009;25:121-6.

Kent RML. The influence of heavy infestations of Polydora ciliata on the flesh content of Mytilus edulis. J Mar Biol Assoc UK. 1979;59:289-97.

Kim BH, Park MW, Kim TI, Cho JK, Son MH, Myeon JI. A study on the optimum stocking density of the juvenile abalone, Haliotis discus hannai net cage culture or indoor tank culture. Korean J Malacol. 2013a;29:189-95.

Kim BH, Park MW, Son MH, Kim TI, Lee SW. A study on the optimum stocking density of abalone, Haliotis discus hannai, reared in net cage culture. Korean J Malacol. 2014;30:219-26.

Kim CW, Lim SG, Kim KS, Baek JM, Park CS. Influence of water temperature on growth and body composition of juvenile abalone (Haliotis discus hannai) fed an artificial formulated diet and macroalgae (Laminaria japonica). J Korean Soc Fish Aquat Sci. 2003;36:586-90.

Kim CW, Kim EO, Jeon HD, Jung CG, Park MW, Son SG. Variation of body composition and survival rate according to spawning of Pacific oyster, (Crassostrea gigas) in Gamak

Bay. Korean J Fish Aquat Sci. 2009;42:481-6.

Kim SY, Park CJ, Nam WS, Kim JM, Lee JH, Noh JK, et al. Comparison of formulated feed and two seaweed-based diets on growth of Pacific abalone (Haliotis discus hannai). Korean J Malacol. 2013b;29:233-8.

Kim TH, Yang MH, Choe MK, Han SJ, Yeo IK. Physiological studies on acute water-temperature stress of juvenile abalone, Haliotis discus hannai. J Aquacult. 2005;18:7-12.

Korea National Statistical Office (KNSO). KOSIS statistical DB. Daejeon, Korea; 2019.

Lee KS. Survival and growth in juvenile abalone Haliotis discus hannai to ocean acidification and elevated temperature. Korean J Fish Aquat Sci. 2014;47:154-9.

Lee SM, Lim YS, Lee JK, Park SR, Myeong JI, Park YJ. Effects of supplemental squid meal, attractant, herb or lecithin in the formulated diets on growth performance in juvenile abalone (Haliotis discus hannai). J Korean Soc Fish Aquat Sci. 1999;32:290-4.

Park EI. Polychaetous annelids growing in oyster farms. Korean Fish Aquat Sci. 1980;13:33-44.

Park MW, Kim H, Kim BH, Son MH, Jeon MA, Lee JS. Changes of survival rate, falling rate and foot histology of the abalone, Haliotis discus hannai (Ino, 1952) with water temperature and salinity. Korean J Malacol. 2013;29:303-11.

Sakai S. Ecological studies on the abalone-IV. J Jpn Soc Fish Sci. 1962;28:899-904.

Shim JH, Jung M. Development and succession of marine fouling organisms on artificial substrata. J Korean Soc Oceanol. 1987;22:257-70.

Shin YK, Jun JC, Im JH, Kim DW, Son MH, Kim EO. Physiological responses in abalone Haliotis discus hannai with different salinity. Korean J Malacol. 2011;27:283-9.

Shin YK, Kim YD, Kim WJ, Park JJ. Survival rate and physiological changes of abalone, Haliotis discus hannai juvenile exposed to different high temperature. Korean J Malacol. 2017;33:157-64.

Yoon HS, Rha SJ, Cha YB, Cho JH, Kim KY, Choi SD. Growth and survival rate on density of Haliotis discus hannai in cage culture. J Korean Soc Fish Aquat Sci. 2004;37:287-94.

Won KM, Kim BH, Jin YG, Park YJ, Son MH, Cho MY, et al. Infestation of the abalone, Haliotis discus hannai, by the Polydora under intensive culture conditions in Korea. J Fish Pathol. 2013;26:139-48. 